\title{
THEORETICAL ASPECTS OF STUDYING THE SYMBOLIC FOUNDATIONS OF LITURGICAL AND SINGING TRADITION
}

\section{Osadcha S. V.}

\section{INTRODUCTION}

The Orthodox liturgical and singing tradition, as a subject of musicological and musical cultural studies, reveals its own special aspects and requires special approaches. First of all, it reveals the liturgical foundations and theological positions as the leading side of her socio-historical formation, and therefore requires knowledge of the Orthodox Church experience in this area. The service pragmatics of the liturgical tradition, however, does not impede its development as a musical phenomenon - in the context of those cultural trends that focus on the latter as a carrier of collective memory.

Issues affecting the preservation and transmission of spiritual values, the evolution of spiritual traditions are the most relevant; they are in priority in modern humanitarian knowledge. In particular, all varieties of Orthodox liturgical singing, their revival and "new life" in the contemporary composer and performing environment are of great interest. Of particular importance are issues related to the systematization of both individual areas of the liturgical and singing tradition, and the tradition of liturgical singing in general.

The liturgical singing cycle, as the musical side of the liturgical and singing tradition, striving for certain autonomy reveals the main symbolic possibilities of Orthodox worship and brings them to an artistic and logical completeness. At the same time, the permanent and supreme purpose of music in the Orthodox rite of succession remains official. Consequently, the liturgical and singing tradition, by virtue of its appeal to the innermost and main symbols of Orthodoxy, clearly reveals the functional dichotomy of the religious and musical genre, and also allows us to answer the question of how acceptable the concept of genre, style, style evolution is in relation to religious ritual experience.

Thus, the topic and problem of our study, having a wide disciplinary resonance, can be most fully disclosed as musicological, since it is the musical side of the Orthodox tradition that makes it possible to identify its important symbolic properties. Moreover, many principles of the formation and development of canons in this tradition, the figurative and semantic purpose of its iconic structures are more deeply revealed in the context of musicology research ${ }^{1}$.

1 Осадчая С. Явление и понятие канона как основа православной богослужебнопевческой традиции: от канонической формы к «духу творчества». Музичне мистецтво $i$ культура. Науковий вісник. Одеса: Астропринт, 2016. Вип. 22. С. 217-225. 
On the other hand, the determination of the genre and style features of the liturgical and singing cycle requires studying it in the context of the integral structure of the Orthodox service, and, therefore, requires knowledge of the ritual features of this service, certain theological justifications, and a specialized culturological approach.

The question of church hymns connection with the context of modern culture is of particular relevance, because today the primary cultural and historical importance of religious and spiritual experience, in particular, Orthodox liturgy, is recognized and comprehended. Composer's experience in the liturgical field shows how the boundaries of liturgical and singing genres imply "implicit correctness" ("let everything be nice and in order...").

The particular importance and theoretical prospects of studying the Orthodox singing tradition, in addition to what has been said, is determined by three factors of modern humanitarian knowledge.

Firstly, the problem of culture as a memory or "memory of culture" is still in its infancy, which is indicated on the pages of the works of S. Averintsev, M. Bakhtin, Y. Lotman, P. Florenskyi that leads to an explanation of the processes of artistic communication, artistic influence, artistic thinking and some others.

Secondly, an extensive theological literature is devoted to the Orthodox service with its special symbolism, in which issues related not only to the cult, but also to issues of the general world order, human consciousness, etc. are addressed. The works of leading theologians, religious philosophers open up the possibility of explanation and analysis of a number of phenomena in sacred music, thus indicating the path of rapprochement between musicological and theological thought in relation to the subject that urgently requires this - in relation to religious and musical tradition. Indeed, today religious and spiritual music has become an active part of culture, has firmly entered the listening consciousness of modern man. On the other hand, its inherent symbolic content cannot be understood and disclosed as it deserves it, without the subject of perception, including the musicologist, knowing about the pragmatics of worship, its statutory requirements, and finally, in the field of the history of Christianity and Orthodox creed.

Thirdly, the liturgical tradition, reaching the individual author's manifestations, allows us to evaluate the style of a number of leading composers who remain either little-known or insufficiently studied precisely as church authors. In this area of composer creativity there is its own musical tradition, which has been actively developing in recent decades in the works of Ukrainian masters; to reveal its supporting points and trends - an urgent task of modern musicologists and cultural experts; the need for this is also due to the fact that almost all modern Ukrainian composers (secular authors) actively take up work in the field of liturgical genres. 
Consequently, the main directions of this study are: the formation of ways to study the Orthodox singing tradition in the context of modern humanitarian knowledge, the creation of a discursive basis for the study of a special semantic phenomenon - "music of worship". These provisions, theoretical positions are determined by the history, structure and cultureforming properties of the Orthodox singing tradition.

\section{The category of memory of culture and its significance in the functioning of the Orthodox liturgical and singing tradition}

One of the most capacious definitions of memory, testifying to its universal cultural and historical significance, was proposed by D. Likhachev, namely: "Memory resists the destructive power of time and accumulates what is called culture" ${ }^{2}$. Close to Likhachev's approach is the position of Y. Lotman, who from a semiotic point of view defined culture as "the totality of all non-hereditary information, how to organize and store it" ${ }^{3}$, that is, defined culture as a special kind of memory. Lotman points to the need for the accumulation and storage of "non-hereditary", "super-genetic" information as the driving mechanism of culture and human self-determination in culture. The phenomenon of culture appears to be subordinate to the functions of memory, since culture is a complex system for storing and transmitting information; it "stores information, constantly developing the most advantageous and compact methods for this, receives a new one, encrypts and decrypts messages, transfers them from one system of signs to another" 4 Thus, just acting as a form of collective memory, culture reaches the level of symbolization that allows us to express the constant antinomies of human existence - "oblivion-preservation", "final-eternal", and "death-immortality" 5

Since, according to the definition of Y. Lotman, culture is a device that generates information, it can be interpreted as an anti-entropy (negentropy) mechanism of planetary human life. It is in connection with this that the culture as a whole and, in particular, the Orthodox culture can be applied to the famous statement of Heraclitus of Ephesus about the self-growing logo of "Psycheya"6, which allows us to understand the logo as an objective meaningful unity of "word" and "meaning". At the same time, according to S. Averintsev, the "word" is not taken in the sensory and sound, but exclusively in the semantic plane, but the "meaning" is understood as something manifest, sign-shaped and therefore

\footnotetext{
${ }^{2}$ Лихачев Д. Поэтика древнерусской литературы. М.: Наука, 1979. С. 42.

3 Лотман Ю. Память культуры. Статьи и исследования. Семиосфера. СПб.: «Искусство-СПБ», 2001. С. 614-622.

${ }^{4}$ Ibid. C. 614-622.

${ }^{5}$ Осадчая С. Память как культурная универсалия и ключевое понятие православного богослужения. Київське музикознавство : НМАУ ім. П. І. Чайковського. Київське державне вище музичне училище ім. Р. М. Глієра. Київ, 2007. Вип. 21. С. 44-54.

${ }^{6}$ Лотман Ю.М. Избранные статьи, Т.1. Таллин, 1992. С. 129.
} 
"verbal"7. However, in order for culture to correspond to its negentropic vocation, it certainly must have inherent complex internal organization, that means, it should be considered as an extensive multi-level system. It should be emphasized that there is an inextricable link between the study of the structural functions of the liturgical and singing system and its consideration as integrity. The service order, strictly defined by worship and dogmatic attitudes, is aimed, first of all, at expressing the deepest meaning, the most fully reflected Word-Logos. And the meaning, in turn, is most literally and fully expressed with the help of the singing side of the service, which, in this way, acquires the ordering stipulated by the church charter. In other words, the semantic purpose of the musical side of the service determines its systemic alignment, and the systemic alignment itself receives the rights of artistic autonomy, consistent with the spiritual idea outside the service and the church, and church outlook. Thus, a different artistic hypostasis of meaning, or another artistic sense of the original order, is achieved. Consequently, the inner trinity of Orthodox culture is most fully revealed and realized through worship and is a reflection of the interaction of its three main components - order - meaning - music.

The problem of culture as a memory or "memory of culture" has more than once become the object of research, for example, in the works of S. Averintsev, M. Bakhtin, Y. Lotman, P. Florenskyi. When studying liturgical texts, we can highlight some of the most frequently used concepts, which should be understood much more widely than they are usually interpreted. These concepts can be regarded not only as part of the texts used in the liturgical order; they should be understood as cultural categories. Such concepts, first of all, include the categorical series - memory - time - collegiality.

Culture as a memory gives rise to special characters, which are the result of the need to protect against death, to overcome the short duration of human life. So, O. Mandelstam argued that "the power of culture lies in a misunderstanding of death" ${ }^{8}$. Culture, in its memorial and protective function, becomes a means of continuously prolonging the life of the human race by creating special temporary criteria. In this regard, Y. Lotman quotes the words of D. Likhachev about the formation in medieval art of such an idea of time at which "... the past was somewhere ahead, at the beginning of events, a number of which did not correspond with the subject perceiving it. The "back" events were events of the present or future. The "back" is the inheritance remaining from the deceased; this is the last thing that connected it with us. "Front glory" is the glory of the distant past, the "first" times; "back glory" is the glory of recent deeds"9.

\footnotetext{
${ }^{7}$ Аверинцев С. Логос. София-Логос. Словарь. К.: Дух і Літера, 2006.

${ }^{8}$ Самойленко А. Музыковедение и методология гуманитарного знания. Проблема диалога. Одесса: Астропринт, 2002. С. 30.

${ }^{9}$ Лотман Ю. Внутри мыслящих миров. Семиосфера. СПб.: «Искусство-СПБ», 2001. C. 356.
} 
Thus, time was perceived as flowing from the past to the future and interchanging these two temporal sections of culture; the past acts as the main value measurement of cultural experience, and the memorial tendency addressed to it becomes an expression of the "deep memory" of culture, marks the eternal, the temporal in the forms of collective cultural consciousness as the only form of immortality accessible to man.

Vladimir Dahl in the "Explanatory Dictionary" interprets memory as the ability to remember the past, the ability not to forget the past. He calls it a specific property of the soul to keep, remember the past. In other words, the protective, memorial function of memory is predominant. The memory of the past is the same as the conclusion, conjecture, and imagination of the future. The fact of V. Dahl's appeal in an article on memory to church services performed in honor of the saints (the days of their memory) and in order to commemorate the dead, that is, to send a special memorial ceremony on a memorial day, is very symptomatic.

The desire to preserve and protect with the help of memory, on the one hand, church, of funeral services, on the other hand, become functionally related phenomena; to a certain extent, worship as a whole can be called an act of memory. Thus, the concept of memory and the concept of death also reveal a certain connection, since death is absolute oblivion, but memory is the only thing that can overcome oblivion. As mentioned above, Florenskyi calls life in paradise the possibility of being in eternal memory (italics is by S. O.) and, as a consequence of this, have eternal existence. Eternal existence is expressed in the possibility of eternal memory in God.

The motto of the Stoic philosophers "memento mori" (Latin "remember death") in the Orthodox Christian dogma is denoted by another concept - "death memory". "In all your affairs, remember your end, and you will never sin" (Sirach, 7, 39) - it is said in the Old Testament book of the Wisdom of Jesus, the Son of Sirach. Out of sin, because of sin, death arose, and the memory of it, of death, can prevent new sins. John Climacus points out that the memory and thought of death gives rise to "uncontaminated purity and endless work". He believes that mortal memory is a blessing, and just like other blessings, it is a gift of God10.

Memory, by the definition of psychologists, is a "natural ability to imagine"11. Plato calls memory the main cognitive function of the mind: "Mother of Muses", that is, the mother of all types of spiritual creativity - this is Memory-Mnemosyne. Knowledge is realized as a remembrance of the

${ }^{10}$ Иоанн (Лествичник, игумен Синайской горы). Лествица. М.: Братство во Имя Всемилостивого Спаса, 1991.

${ }^{11}$ Пфендер А. Введение в психологию. СПб., 1909. С. 294. 
transcendental world. In other words, earthly, longitudinal knowledge is a remembrance of the highland ${ }^{12}$.

Father Pavel Florenskyi in the book "Pillar and the statement of truth" gives the views of two famous philosophers on this issue. Florenskyi points out that, if according to Kant, transcendental memory is the basis of knowledge, then transcendental memory is the basis of knowledge, according to Plato. "And if, further, we notice that the "transcendental" in Kant has a clearly transcendental meaning, and the "transcendental" in Plato can be interpreted as "transcendental", then the affinity of thoughts of the two greatest philosophers will become undeniable"13. To the opinion of these two prominent philosophers, Florenskyi also adds the views of a XX representative of the philosophy of the 20th century, Henri Bergson, who said that memory is the activity with which "we enter the realm of the spirit" (H. Bergson), and through memory man becomes a spiritual being self-conscious, by itself. Based on this, we, following Florenskyi and Bergson, can conclude that the whole theory of knowledge is a theory of memory.

What is memory as a "soul activity", what is its ontological moment? According to Pavel Florenskyi, this is "mental creativity", "the only creativity inherent in thought" ". He calls fantasy and prediction of the future a kind of memory. Memory "is the activity of mental assimilation, that is, the creative recreation of ideas, the one which is revealed by mystical experience in Eternity, or, in other words, the creation in Time of Eternity symbols" ${ }^{15}$. Florenskyi thus indicates the fluidity and short duration of phenomena in time. Heraclitus said: "Everything flows and moves, and nothing abide" ${ }^{16}$.

The very essence of life and time lies in their fluidity and oblivion. The only thing that can be contrasted with the short duration of life and the fluidity of time is memory. Florenskyi claims that we are able to remember not psychological, but mystical elements, since "psychological is psychological because they occur in Time and irrevocably flow away from Time"17. It is impossible to repeat one or another psychological element, just as it is impossible to repeat the time with which it was associated. Father Paul calls the life of the psychological element "one-moment".

The very desire to remember goes beyond the boundaries of rational activity: this is an expression of the desire for non-oblivion. In order to once again touch the reality that was already experienced once, a certain "mystical" (Florenskyi), symbolic effort is necessary in order to rise above Time. Thus, memory always exists as a transcendental phenomenon, and in it we can see

\footnotetext{
${ }^{12}$ Флоренский П. Столп и утверждение истины. М.: Аст, 2003. С. 177.

${ }^{13}$ Ibid. C.177-178.

${ }^{14}$ Ibid. C. 178.

${ }^{15}$ Ibid. C. 178.

${ }^{16}$ Ibid. C. 44.

${ }^{17}$ Ibid. C. 44
} 
the manifestation of our supra-temporal nature. Thanks to this, we are able to perceive simultaneously the past moment of Time both as the past and how it is happening now, in the present tense, that is, all Time has been given to us, like some kind of "now", and looking at all Time, it is above Time.

The problem of memory correlates with the chronotopic approach to the history of culture, with the temporal and spatial dimension of culture. So, S. Averintsev wrote that if the world of Greek philosophy and Greek poetry appears as a cosmos, that is, as a "law-shaped and symmetrical spatial structure", then the Christian world, the world of the Bible is "olam"18. "Olam" is understood by him, on the one hand, as "antiquity," the initial great time, and on the other, as "future". Averintsev describes the "olam" as "two dark abysses of time behind and in front of man"; this word "means "eternity", not in the sense of motionless withdrawal from time, but in the sense of the totality and completeness of time. More precisely, this is not "eternity", but "world time", which, firstly, moves and, secondly, can end and be replaced by another "olam", another state of time and things in it" ${ }^{19}$. Thus, the Greek "cosmos" settles down and rests in space, revealing and demonstrating its boundaries and its inherent measure, while the biblical (later Christian) "olam" is located and moves in time, "rushing towards the meaning that passes over its limits" 20 .

N. Berdyaev calls the problem of Time the main problem of history philosophy and modern philosophy ${ }^{21}$. The problem of time, according to Berdyaev, can be interpreted from two points of view:

1) as it is interpreted in mathematical philosophy, where time is calculated mathematically;

2) as it exists for existential philosophy, where time is transcendental; it cannot be objectified and is not subject to the category of number.

Berdyaev calls our historical time a disease, an eternity, which has disintegrated into its components (into the present, past and future). From this angle, hell can be described as the need to remain in "sick time", the impossibility of getting out of this time.

In general, it is difficult to name a more general problem for various branches of human knowledge than the problem of time. Being fundamental to scientific knowledge, both in the humanities and in the natural sciences, as well as for the exact sciences, it nevertheless remains difficult to solve, not completely amenable to the logic of scientific rationalization. Therefore, A. Pigalev is right when he points out that "... both the abstract time of

${ }^{18}$ Аверинцев С. Поэтика ранневизантийской литературы. СПб.: Азбука-классика, 2004. C. 94.

${ }^{19}$ Ibid. C. 269.

${ }^{20}$ Ibid. C. 96.

${ }^{21}$ Бердяев Н. Вечность и время. Вестник РХД. Париж-Нью-Йорк-Москва, 1998. C. $135-140$. 
mathematical natural science and the specific time of everyday life and history have a definite, although different semantic content for a person, and the former does not have any "birthright" with respect to the latter. We are talking about various goals and levels of understanding the time of culture. In accordance with this, it speaks of biological, psychological, physical, geographical, etc. time. Moreover, "abstract" time does not precede "concrete", but, on the contrary, "builds up" over the corresponding images and cannot exist without them. Everything that exists has temporal characteristics, which makes it impossible to define time in its classical sense as assigning it to a certain genus and listing species characteristics. Time cannot be attributed to any "kind", and therefore all its definitions are tautological and use associations combined with it or seek to express its essence using the properties inherent in space" (italics is by S. O.) ${ }^{22}$.

In the above-mentioned thoughts on the phenomenon of time, in our opinion, the specific features of time are concentrated in his relations with man and human knowledge. Firstly, time is a semantic phenomenon - as a result of the meaningful work of human consciousness, which immediately indicates its qualitative filling and significance for a person, followed by quantitative (technological, mechanical) approaches to time (and the history of inventive human thought confirms this); secondly, the perception of time is holistic, since, on the one hand, it is part of the formation of the "image of the world", and on the other hand, it is based on the unity of figurative and rational thinking with a primary position of the first; thirdly, time always acts as a conceptual phenomenon based on the experience of a person's activity in a certain cultural field (including its participation in life, which is also a component of culture for a person), that is, it is defined and understood in an indirect way, by spatialization - objectification, with the help of hypostatic imaginations - with all the corresponding "difficulties in translating" a particular experience into an abstract imagination; fourthly, the inevitable, hence the necessary metaphor of the time concepts makes it particularly important in its awareness, expression in the cultural semantics of an artistic understanding of time and the symbolism associated with it; fifthly, in this regard, time in music - musical time is in no way inferior to other forms of temporary imaginations under the "birthright", it gives rise to its own temporal patterns and chronotopic dimensions, the study of which can clarify the general cultural concepts of time, for example, its modal structure.

Therefore, this is the first consideration of the features of time phenomenon in human culture and in human consciousness, which allows us to define it as a complex mediated reflection of a person's relationship to the world, which involves self-esteem - an analysis of emerging imaginative 1997. C. 81 .

${ }^{22}$ Культурология. XX век. Словарь. Санкт-Петербург : Университетская книга, 
representations, and some creative mental activity - finding ways of sign expression, that is rationalization of these imaginations. This rationalization, as it was already noted, takes place in various branches of knowledge.

Aristotle also wrote that various modes of time are known through various human abilities. In experience, reality, the present is known. The present is that mode or that part of the time that convinces us of the reality of this phenomenon itself. As for the past, it is reflected with the help of memory, and among the functions of memory there is "the ability to forget" (L. Vygotskyi). In this case, the process of remembrance comes into force, as a synthesis of the "former" and "non-former" with the subject, as the "imaginative play of consciousness" (L. Vygotskyi).

\section{Prolegomens to the study of time phenomenon in the liturgical and singing culture: a semiological aspect}

The modus of the future is an exceptionally complex modus of time. Psychologists have shown that there are real mechanisms that ensure the process of building models of the future, which also represent a synthesis, a certain correlation of images of reality and ideal - fictional - constructions. Therefore, the time phenomenon in its integrity, given the relationship between the past, present and future, we can say that it is integrative or synthetic in nature, it combines reality and illusion. The phenomenon of time cannot be attributed only to "real" or only to "illusory" objects.

Noteworthy thoughts about time were expressed by Blessed Augustine in his "Confession"23. Augustine revealed the illusory nature of time, noting that the past is no more; the future is not there, the present is continuously breaking up into the future and the past and that is why it is elusive. In other words, not a single part of time is elusive, and therefore time is ghostly. Augustine assumed the existence of three options for the present - the present present, present past and present future. V. Rudnev defines the understanding of time by Blessed Augustine as semiotic. The beginning of the history of mankind - or, as Augustine calls it, Rudnev, "the plot of drama" - is the fall in sins. The punishment for disobedience and, as a consequence of this disobedience, - the forced existence of man in entropy time becomes a sin. In other words, a person is deprived of immortality and becomes able to again be involved in Eternity only after the coming of Christ. Jesus Christ "atonement" in the death on the cross of human sins "turned time" towards atonement and Rudnev calls this new kind of time as eschatological or semiotic. V. Rudnev explains the use of the semiotic term in relation to time by the fact that Augustine, presenting history as a drama, involuntarily considers it as a work of art - as a sign system ${ }^{24}$.

${ }^{23}$ Августин (Блаженный). Исповедь / Пер. с лат. М. Сергеенко; Предисловие и послесловие Н. Григорьевой. М.: Гендальф, 1992.

${ }^{24}$ Руднев В. Словарь культуры ХХ века. М.: Аграф, 1997. С. 60-63 
Based on this, "memory is symbolic creation” (P. Florenskyi), creation of symbols. Symbols can be placed in the past (then they are called memories), in the present (imagination) and in the future (foresight, according to Berdyaev a prophecy). But the past, the present, and the future, in order to be a place for symbols, must themselves be experienced simultaneously, that is, under the "angle of Eternity". In all three arrangements of symbols, "the activity of thought sets forth Eternity in the language of Time; the act of this utterance is memory" 25 . N. Berdyaev points out that between the past, which was once the present, and the present, there is a transforming act of memory. "Memory is a miracle in human existence, it is a transforming act of changing the past (idealization of the past, or vice versa); in the past, there has never been what in the present we affirm about the past. A creative act of memory brings us to the past”26. Thus, memory is the creative principle of thought, thought in thought. Divine thought becomes the most perfect creativity, and God's creativity is His memory. "God, remembering, thinks, and thinking, He creates" 27.

The question of temporality (short-temporality) and eternity actualizes the question of the "last problem of time - the Apocalypse" (N. Berdyaev). The Apocalypse is a very mysterious text that raises the question of the relationship between Time and Eternity. In this sense, the Apocalypse represents the paradox of time awareness. N. Berdyaev spoke of a similar paradox, indicating that we cannot "get rid of the position that eternity will someday come in the future" (italics is by S. O.) ${ }^{28}$. In the Apocalypse, the paradox of the relationship to time is expressed and overcome by the words: "There will be no more time," in other words, there will be a time when there will be no time. Therefore, the time of Eternity is not subject to exact, mathematical calculus.

One of the most important topics of the Apocalypse is the blurring of differences between the past, present and future. Thanks to this, it becomes possible to remove the distinction between "already" and "not yet" (Averintsev), and the mystical historicism of eschatology easily turns into a negation of historicism as such. The end of the present being of the world is an event that means a way out of time, the victory of Eternity over Time. Understanding of such an event is not available for rational logical thinking, therefore, in the Apocalypse this way out of time is expressed in symbols, which conceal the truth about "biased time" (N. Berdyaev).

The composer interpretation of the theme of death - time - memory eternal memory depends in many respects on the individual ideas of the author about death and eternal life, while the collegiate church experience

\footnotetext{
${ }^{25}$ Флоренский П. Столп и утверждение истины. М.: Аст, 2003. С. 179.

${ }^{26}$ Бердяев Н. Вечность и время. Вестник РХД. Париж-Нью-Йорк-Москва, 1998. С. 137.

${ }^{27}$ Флоренский П. Столп и утверждение истины. М.: Аст, 2003. С. 179.

${ }^{28}$ Бердяев Н. Вечность и время. Вестник РХД. Париж-Нью-Йорк-Москва, 1998. С. 139.
} 
can realize this significant and large-scale theme in all collective breadth and fullness. Eschatology and eschatological moods are transferred and often interpreted as an area of personal hope, personal expectation. This, of course, takes place, however, the entire Christian worship in all its existing varieties is generally eschatological, and it is the focus of the whole experience of church life ${ }^{29}$.

The problem of time for musical culture is very characteristic and specific; it has already been reflected in a number of studies on this topic. The temporal nature clearly appears in music and, one might say, the very course of time becomes noticeable, expedient. "Art reveals special ways of owning time - living it as the present, saturates the present with sense, rivets the consciousness to it, preventing it from slipping into the realm of memories or predictions (dreams), makes it present, acutely sensing every moment of the current time and joining in it with -experience; ... in the act of artistic creation, the boundaries between the present and the future are erased, it is directed to the fact that "forever", and thus the past is joined to the unity of time: that which is forever the basis of future memory, on the basis of which they will judge about the present, and about the past" ${ }^{30}$. Thus, time in music has a completely cultural nature in the same sense as the very essence of man is a condition and at the same time a "product" of the existence of culture.

Based on the foregoing, we can conclude that in a completely paradoxical way, the problems of time and death (as the beginning of eternal life) - time and music, in a number of supporting moments, are interlocked. So, the words of the Apocalypse that there will come a time for mankind when there will be no time, merge with the words of Pavel Florenskyi that "music ceases to be only in time, but also rises above time" ${ }^{31}$.

Of all the above works, including Father Pavel Florenskyi, the concept of memory as a universal of Orthodox worship and the whole church culture as a whole is created. "Deep memory is provided by the presence of linguistic elements, which, firstly, are subject to change (complete immutability makes memory unnecessary), and secondly, have the ability to persist in the system both in their invariance and in their

${ }^{29}$ Абсолютно все виды православного богослужения включают молитвы об упокоении, об ожидании конца, но сосредоточением молитв такого рода становятся заупокойные службы и службы Великого поста. Причем помимо общей эсхатологической направленности в заупокойных и великопостных службах присутствует не просто тематическое сходство, а абсолютная идентичность ряда текстов, в том числе и музыкальных (например, великий канон Андрея Критского «Помощник и покровитель», который поется на Первой неделе Великого Поста и при отпевании священников и архиереев).

${ }^{30}$ Самойленко А. Музыковедение и методология гуманитарного знания. Проблема диалога: [Монография]. Одесса: Астропринт, 2002. С. 47.

${ }^{31}$ Флоренский П. Исследования по теории искусства. Статьи и исследования по истории и философии искусства и археологии. М.: Мысль, 2000. С. 213. 
variability. As a result, one and the same element, penetrating different states of the system, like connects them together" ${ }^{32}$.

In relation to the church and singing tradition, the above thought of Y. Lotman is especially important, since it contains an indication of two fundamental tendencies of memory, and therefore, the church and singing tradition is broader - the culture that this tradition represents. In general, the experience of spiritual musical culture demonstrates the active interaction of these two of its main tendencies, which, according to the terminology of M. Bakhtin, can be defined as a protective memorial and familiar mnemonic.

These trends as major in the formation of artistic consciousness and the accompanying genre forms of expression are defined in the work of M. Bakhtin "Epic and Romance" ${ }^{33}$. So, M. Bakhtin singled out three "constitutive traits" that separate the epic (preservative and memorial tendency) from the novel (familiar and mnemonic tendency):

1) the subject of the epic is the national epic past - as an "absolute past”. The subject of the preservation and memorial trend is Orthodox dogma and eschatology, what we can call an "absolute past" that cannot be overestimated by the semantic thesaurus of the Christian worldview;

2) the source of the epic is national tradition (and not personal experience and free fiction growing on its basis). As a source of the protective and memorial tendency, we find church tradition, generalized conciliar experience, "churchiness" in the understanding of Florenskyi;

3) the epic world is separated from modernity, that is, from the time of the singer (author and his listeners), by an absolute value distance. And in the preservation and memorial tendency, we also observe "absolute distance", like an epic that has never been a poem about the present, about its time. Just as from the very beginning the epic was a "poem about the past", the protective and memorial tendency is aimed at "deep memory" 34 .

It is interesting to observe that historical time is a constant background of human activity, regardless of the degree of its observance, severity. The subject of dialogue is always the subject of history - only at its different levels, depending on the responsibility of the dialogue. Even a personal story a biography - does not occur aside from social life, but is motivated by the last one. Therefore, the responsibility of artistic creation is associated with the search for historical, that is, necessary at the moment, the formation of culture, authorities.

${ }^{32}$ Лотман Ю. Память культуры. Статьи и исследования. Семиосфера. СПб.: «Искусство-СПБ», 2001. С. 616.

${ }^{33}$ Бахтин М. Эпос и роман. Вопросы литературы и эстетики. Исследования разныхх лет. М.: Художественная литература, 1975. С. 447-484.

${ }^{34}$ Ibid. C. 456. 
The reference to authority, the attraction of authoritative judgment to one's side - this is quotation - an important argument of the art forms. Such a sought-after authority is tradition, moreover, both genre and style. The general cultural prototype of the interaction - the confrontation between the canonical and the "free-thinking" tradition - its violation (the author's "impudence") can be considered the antinomy of the ritual - carnival, from which Bakhtin derived his theory of carnival and his concept of chronotope ${ }^{35}$.

Therefore, such phenomena (and concepts about them) as culture time - symbol - memory are in constant interdependence, but it is memory that becomes central to the rest, forms the axis of their interaction, and the concept of memory is at the intersection of central cultural concepts. The phenomenon of memory is an integral part of the movement from sense to its symbolic expression and from symbol to finding its deepest meanings; it plays a leading role in the process of cultural overcoming the temporal limitations of life. In relation to the Orthodox singing tradition, memory proves its significance as a cultural universal, becoming a semantic dominant and defining its specific ways of symbolizing, therefore, embodied in concrete symbolic forms, ritual, verbal and musical.

\section{CONCLUSIONS}

The liturgical and singing tradition, reaching the individual author's manifestations, allows us to evaluate the style of a number of leading composers who remain either little known or insufficiently studied precisely as church authors. In this area of composer creativity there is a system of semantic priorities and, accordingly, semantic preferences (dominant); to reveal its key points and trends is an urgent task for a musicologist, the need for which is also due to the fact that modern secular composers, including Ukrainian ones, are actively taking up work in the field of liturgical genres.

Religious and church culture, perceived as integrity, as a single organism, is a coordinated, organic interaction of its subsystems, one of which is the liturgical and singing tradition. D. S. Likhachev, whose theory of culture is of particular importance to us, pointed to two main, from his point of view, cultural properties - integrity and historicity. He emphasized that the concept of culture, as a complex one, embraces the phenomena of religion, science, education, moral standards of behavior of people and the state ${ }^{36}$; in other words, culture is a single space and a way of preserving human existence. "Unlike the general movement of "civil" history, the process of cultural history is not only a process of change, but also a process of preserving the

35 Самойленко А. Диалог как музыкально-культурологический феномен: методологические аспекты современного музыкознания. Дис. на соиск. учен. степ. доктора искусствоведения. Одесса, 2003. С. 30.

${ }^{36}$ Лихачев Д. Поэтика древнерусской литературы. М., 1979. 
past, the process of discovering the new in the old, and the accumulation of cultural values”37. A similar axiological approach is also characteristic of Father Pavel Florenskyi, who believed that culture, as a phenomenon of a religious order, in its center contains "the seed of true humanity", "the bud of spiritual integrity", and therefore "the bud of culture" is the cult "in the narrow sense of the word" - that is, liturgical service ${ }^{38}$.

This systematic approach becomes, in our opinion, a decisive prerequisite for, firstly, considering the religious and church culture as an independent historical and stylistic phenomenon; secondly, to discuss the artistic form that forms the formative side of culture as not only necessary, but assuming special logical obligations that initiate the impact and perception of religious and church action. This artistic side of the "liturgical ministry" also has its own stylistic dichotomy, if we follow Losev's thought, namely: direct introduction to the semantic content of the service, its holistic perception as "world-feeling", at the same time, the individualization of sensory perception is ensured by the music and song side, while the principles of the liturgical organization, which give it "balance, logic, peace", are ensured by the spectacular and plastic side of the rite (it is not by chance that so many attention is given in the works of P. Florenskyi).

The canonical verbal side of the liturgical rite, like all its verbal elements, facilitates the interaction of the external-visual and internal-auditory sides, strengthens the "rational" orientation of worship, at the same time being saturated with musical-auditory emanations and acquiring some symbolic encryption - in case of direct connection with the song. Thus, the religious and church tradition can be considered as a stable model of the "worldview style", which, in turn, is a special spiritual phenomenon that characterizes the cognitive activity of a person and its value and semantic results.

Turning to sacred religious meanings, the church tradition also appeals to the highest methods available for a person to measure the spiritual, suggesting the way to the so-called "indescribable", anagogical meanings, or rather, proving the primary importance of this particular form of meaning not subject to verbal rationalization. Consequently, the musical and singing content of the liturgical rite also rises to the ultimate anagogical semantic height. Not without reason did John Chrysostom emphasize that the one who rejoices, does not speak words; "The powers of heaven sing hymns, not psalms..." ${ }^{39}$.

37 Лосев А. О мироощущении Эсхила. Форма - Стиль - Выражение. М., 1995.

${ }^{38}$ Флоренский П., свящ. Философия культа (опыт православной антроподицеи). М.: Мысль, 2004. С. 58.

39 Давыдов И.П. Специфика русского акафистографического наследия в свете религиоведческой проблематики. Вестник Московского университета. Серия 7. Философия. №4. М., 2002. С. 62. 
Consequently, the basis of the musicological discourse of the Orthodox singing tradition is the conceptual triad of memory - time - collegiality, as well as the concepts of symbol, style and genre, musical and liturgical style, churchiness, anagogical meaning. The connection arising between these concepts indicates the possibility of studying the Orthodox singing tradition as a single text. They form a solid logical basis for a systematic study of Orthodox singing, since they interact with each other; enter into complexmediated relationships, revealing special semantic intentions of the Orthodox consciousness.

\section{SUMMARY}

In this study, the Orthodox singing tradition appears as a complex semantic phenomenon that requires a special systematic approach. It takes on her its genre and style forms, develops its own measure of artistry as a manifestation of a creative trend. The realization of this trend throughout the history of Orthodox liturgical culture is music, or rather, a special system of singing norms that has developed on the basis of prayer texts. Thus, the Orthodox singing tradition, or "music of worship", as defined by P. Florenskyi, reflecting the historical dynamics of religious tradition, becomes the main indicator of its semantic evolution, represents the procedural side of liturgical symbolism, in other words, allows you to recognize the symbolic meanings that accumulate, being conditioned contextually.

The Orthodox liturgical and singing tradition appeals to memory in its sociocultural significance and makes the memory phenomenon leading, especially noticeable; in particular, it allows one to notice what the phenomenon of memory is associated with in musical creativity. In this regard, the substantiation of the significance of memory as a cultural universal, the definition of the semantic function of the concept of memory in Orthodox worship, and also the correlation of the phenomenon of memory with a chronotopic approach to the history of culture, with the temporal and spatial dimension of culture, are particularly relevant.

In relation to the Orthodox singing tradition, memory proves its significance as a cultural universal, becoming a semantic dominant and defining its specific ways of symbolizing, therefore, embodied in concrete symbolic forms, ritual, verbal and musical.

In connection with Orthodox singing and its genre and style features, the text appears as that aspect of the work in which it is in its temporary hypostasis, while the work, in turn, is the result of the implementation of the temporal side of the text. In other words, a text is always a process, and a work is a consequence of a reducing and generalizing synthesis. A systemological study of Orthodox singing culture allows us to clarify and deepen textology as a discipline that has independent and very significant 
tasks, including the task of characterizing the text as a historiological category, with an ascent to those original samples of the text that determine its canonical properties, as well as determining as the most important, chronotopic functions of the text.

\section{REFERENCES}

1. Августин (Блаженный). Исповедь / Пер. с лат. М. Сергеенко; Предисловие и послесловие Н. Григорьевой. М.: Гендальф, 1992. 544 с.

2. Аверинцев С. Логос. София-Логос. Словарь. К.: Дух і Літера, 2006. C. $277-278$.

3. Аверинцев С. Поэтика ранневизантийской литературы. СПб.: Азбука-классика, 2004. 480 с.

4. Бахтин М. Эпос и роман. Вопросы литературы и эстетики. Исследования разных лет. М.: Художественная литература, 1975. С. 447484.

5. Бердяев Н. Вечность и время. Вестник РХД. Париж-Нью-ЙоркМосква, 1998. С. 135-140.

6. Иоанн (Лествичник, игумен Синайской горы). Лествица. М. : Братство во Имя Всемилостивого Спаса, 1991. 220 с.

7. Культурология. XX век. Словарь. Санкт-Петербург : Университетская книга, 1997. $631 \mathrm{c.}$

8. Лихачев Д. Поэтика древнерусской литературы. М.: Наука, 1979. $360 \mathrm{c}$.

9. Лосев А. О мироощущении Эсхила. Форма - Стиль Выражение. М., 1995. С. 781-880.

10. Лотман Ю. Внутри мыслящих миров. Семиосфера. СПб.: «Искусство-СПБ», 2001. С. 150-392.

11. Лотман Ю. Память культуры. Статьи и исследования. Семиосфера. С.-Пб.: «Искусство-СПБ», 2001. С. 614-622.

12. Лотман Ю. Избранные статьи. Ю. М. Лотман. Избранные статьи. В 3-х т.т. Таллин: Александрия, 1992. Т.1. С. 129-132

13. Осадчая С. Память как культурная универсалия и ключевое понятие православного богослужения. Київське музикознавство : НМАУ ім. П. І. Чайковського. Київське державне вище музичне училище ім. Р. М. Глісра. Київ, 2007. Вип. 21. С. 44-54.

14. Осадчая С. Явление и понятие канона как основа православной богослужебно-певческой традиции: от канонической формы к «духу творчества». Музичне мистецтво і культура. Науковий вісник. Одеса: Астропринт, 2016. Вип. 22. С. 217-225. 1909. $368 \mathrm{c}$.

15. Пфендер А. Введение в психологию. СПб.: Провинция,

16. Руднев В. Словарь культуры ХХ века. М.: Аграф, 1997. 384 с. 
17. Самойленко А. Диалог как музыкально-культурологический феномен: методологические аспекты современного музыкознания. Дис. ... доктора искусствоведения. 17.00.03. Одесса, 2003. 437 с.

18. Самойленко А. Музыковедение и методология гуманитарного знания. Проблема диалога: Монография. Одесса: Астропринт, 2002. 244 с.

19. Флоренский П. Исследования по теории искусства. Статьи и исследования по истории и философии искусства и археологии. М.: Мысль, 2000. С. 79-391.

20. Флоренский П., свящ. Столп и утверждение истины: Опыт православной теодицеи. М.: ООО «Издательство АСТ», 2003. 640 с.

21. Флоренский П., свящ. Философия культа (опыт православной антроподицеи). М.: Мысль, 2004. 685 с.

Information about the author: Osadcha S. V., Doctor of Arts, Professor of the Department of Music History and Musical Ethnograph, Odessa National A. V. Nezhdanova Academy of Music 63, Novoselskogo str., Odessa, 65023, Ukraine 